\title{
Prevalence of diarrheogenic Escherichia coli and rotavirus among children from Botucatu, São Paulo State, Brazil
}

J. Rodrigues ${ }^{1}$, V.C. Acosta ${ }^{1}$, J.M.G. Candeias ${ }^{1}$, L.O. Souza ${ }^{1}$ and F.J.C. Filho ${ }^{2}$
${ }^{1}$ Departamento de Microbiologia e Imunologia, Instituto de Biociências, and ${ }^{2}$ Centro de Saúde Escola, Universidade Estadual Paulista, Botucatu, SP, Brasil
Correspondence

J. Rodrigues

Departamento de Microbiologia

e Imunologia

Instituto de Biociências, UNESP

Campus de Botucatu

18618-000 Botucatu, SP

Brasil

Research supported by FAPESP (No. 1997/07733-9 to J. Rodrigues).

Received July 19, 2001 Accepted August 20, 2002 $\ldots \ldots \ldots \ldots \ldots \ldots \ldots$

\section{Abstract}

In a one-year prospective study carried out to define the role of rotavirus and Escherichia coli in local childhood diarrhea, we determined the prevalence of both agents in 54 diarrheic children attending a health center in Botucatu. Diarrheogenic E. coli (DEC) strains were characterized by O:H serotyping, a search for virulence genetic markers, and assays of adherence to HEp-2 cells. Except for enteroaggregative $E$. coli (EAEC), no other DEC category was detected in the children's stools. Both EAEC and rotavirus were isolated from 22 of the $54(41.0 \%)$ diarrheic children as single agents or in combination with other enteropathogens. However, when considering the presence of a single agent, EAEC was dominant and isolated from $20.4 \%$ of the patients, whereas rotavirus was detected in $14.8 \%$. These results indicate that rotavirus and EAEC play a significant role as agents of childhood diarrhea in the local population.

\section{Introduction}

Infectious diarrhea is a leading cause of morbidity and mortality worldwide, affecting mainly infants. Rotavirus and diarrheogenic Escherichia coli (DEC) are considered to be some of the most common of the many recognized enteropathogenic organisms, the first on a global scale (1), with DEC being particularly important in developing countries (2).

Rotavirus, an icosahedral virus belonging to the family Reoviridae, was first recognized as a diarrhea agent by Bishop et al. in 1973 (3). Rotavirus diarrhea frequently occurs in the fall and winter in temperate cli-
Key words

- Diarrhea

- Rotavirus

- Enteroaggregative E. coli

- Escherichia coli

- Seasonality mates, but in tropical settings and in developing countries a defined seasonality has not been observed (1).

The differentiation of DEC from commensal E. coli is based on serotyping and screening of clinical isolates for typical virulence factors, symptoms of diarrhea and the patient age group with which they are associated. The application of these criteria has permitted the identification of the five currently recognized DEC categories: enterotoxigenic $E$. coli (ETEC), enteroinvasive $E$. coli (EIEC), enterohemorrhagic E. coli (EHEC), enteropathogenic E. coli (EPEC), and enteroaggregative E. coli (EAEC) (4). ETEC are distinguished by the ability to 
produce enterotoxins and to express some colonization factors (5). EIEC can be identified, among other criteria, by their epithelial cell invasiveness and association with dysentery (4). EHEC, an agent of a form of hemorrhagic colitis and hemolytic uremic syndrome, can be differentiated mainly by the ability to produce Shiga cytotoxins (6). EPEC have as a characteristic identification mark the capacity to express localized adherence and to induce attaching and effacing lesions on cultured epithelial cells (7) and, in contrast to other DEC, are associated only with infantile diarrhea (4). EAEC are also distinguished by their typical adherence to cultured cells, i.e., the aggregative adherence pattern (4). Some investigators add to the DEC list a sixth category, diffusely adhering E. coli (DAEC), also identified by the adherence pattern to cultured cells, but whose association with enteric diseases has not been firmly established (4).

In spite of the availability of modern, rapid and easy-to-use diagnostic techniques such as PCR to identify virulence genes, screening for DEC categories is not routinely employed in Brazilian clinical laboratories. Thus, by screening for the presence of rotavirus, isolating and characterizing $E$. coli from a local population of diarrheic children, the objective of the present study was to determine the extent of the participation of these agents in the etiology of diarrhea in this population.

\section{Material and Methods}

\section{Patients and enteropathogen isolation}

The study was carried out from June 1997 to May 1998, a period during which 54 diarrheic children attended Centro de Saúde Escola (Teaching Health Center) in Botucatu. Twenty-six patients were less than one year old, 25 were 1 to 5 years old and three were 5 to 13 years old. General information on clinical history, socioeconomic status and living conditions of the patients was obtained and recorded on a standard form by a pediatrician. Immediately after collection, patients' stools were divided into two portions, one of which was preserved in a transport solution destined to bacterial isolation and the other transferred to a disposable flask for rotavirus detection. Bacterial isolation and identification were performed by standard procedures (8) within $24 \mathrm{~h}$ of stool collection.

Rotavirus detection was performed in freshly collected or in freezer-preserved stool samples by RNA extraction, separation by polyacrylamide gel electrophoresis, silver staining and analysis with a white light transilluminator(Vilber Lourmat, Marne La Vallee Cedex, France) for the presence of the characteristic 11 double-stranded RNA segments (9).

\section{Characterization of $E$. coli isolates}

$O$ typing. The E. coli isolates were serotyped with antisera (Probac do Brasil Ltda., São Paulo, SP, Brazil) to EPEC classical O serogroups (O26, O55, O86, O111, O114, $\mathrm{O} 119, \mathrm{O} 125, \mathrm{O} 126, \mathrm{O} 127, \mathrm{O} 128, \mathrm{O} 142$, and O158) by slide agglutination. Anti-O reactive isolates were further tested with anti- $\mathrm{H}$ antisera specific for $\mathrm{H} 2, \mathrm{H} 4, \mathrm{H} 6, \mathrm{H} 7, \mathrm{H} 8$, H9, H10, H12, and H21.

$H$ typing. Production of the anti-H antisera as well as the serological reactions to detect the $\mathrm{H}$ antigens followed the procedures recommended by Edwards and Ewing (10). Briefly, cultures of $\mathrm{H}$ reference strains (kindly provided by Dr. L.R. Trabulsi, Laboratório Especial de Microbiologia, Instituto Butantã, São Paulo, SP, Brazil) stimulated for maximum expression of flagellar antigens were suspended and adjusted to about $10^{9} \mathrm{CFU} / \mathrm{ml}$ in PBS, formaldehyde inactivated, and inoculated into adult rabbits at four increasing doses: 1 st week, $0.5 \mathrm{ml} ; 2 \mathrm{nd}$, $1.0 \mathrm{ml} ; 3 \mathrm{rd}, 2.0 \mathrm{ml}$, and 4th, $4.0 \mathrm{ml}$. After a final $4.0-\mathrm{ml}$ booster dose during the 5 th week and a resting period of 20 days, the rabbits 
were bled and specific anti-H antisera were obtained. The $\mathrm{H}$ typing was performed by serial dilutions of anti-H antisera in formaldehyde-saline suspensions of the $E$. coli to be tested and by checking the tubes for the occurrence of agglutination after a 4-h incubation period in a $48^{\circ} \mathrm{C}$ water bath.

Adherence assays. Bacterial adherence was tested in HEp-2 cell monolayers grown to full confluence on chamberslides (Nalge Nunc, Rochester, NY, USA) according to the procedures described by Cravioto et al. (11). Briefly, $20 \mu \mathrm{l}$ of an overnight bacterial culture was added to the cell monolayers and incubated for $3 \mathrm{~h}$ at $37^{\circ} \mathrm{C}$ in Eagle's minimal essential medium (Sigma, St. Louis, MO, USA) with $1.0 \%$ D-mannose and supplemented with $10 \%$ fetal calf serum. After incubation, the monolayers were rinsed in PBS, fixed in methanol, stained and examined under the microscope for the expression of characteristic adherence. Isolates unable to adhere during a 3-h incubation period were again tested under the same conditions during a 6-h incubation period.

PCR for detection of DEC virulence genes and plasmids

The following genetic virulence markers were determined: EAEC plasmid, Shiga cytotoxins 1 and $2(s t x 1, s t x 2)$ genes and E. coli attaching and effacing (eae) gene of EPEC and EHEC, bundle-forming pilus ( $b f p A$ ) gene of EPEC, invasion-associated locus ( $\mathrm{ial}$ ) of EIEC and heat-stable ( $s t a$ ) enterotoxin gene of ETEC. The template DNA was added to the reaction mixture as a whole bacterial lysate prepared from overnight cultures in trypticase soy broth as follows. A culture aliquot of $1.0 \mathrm{ml}$ was transferred to $1.5-\mathrm{ml}$ polypropylene tubes (Eppendorf) and centrifuged and the supernatant was discarded. The pelleted cells were resuspended in 1.0 $\mathrm{ml}$ of distilled water, heated to boiling for 10 min and immediately placed in an ice bath. The PCR mixture had a final volume of 100 $\mu \mathrm{l}$ consisting of reaction buffer $(5 \mathrm{mM}$ Tris$\mathrm{HCl}, \mathrm{pH} 8.0,10 \mathrm{mM} \mathrm{NaCl}, 10 \mu \mathrm{M}$ EDTA, $0.1 \mathrm{mM}$ DTT, $5.0 \%$ glycerol, $0.1 \%$ Triton $\mathrm{X}-100), 0.15 \mathrm{mM} \mathrm{MgCl} 2,0.2 \mathrm{mM}$ of each dNTP (dATP, dCTP, dTTP and dGTP), 0.2 $\mathrm{mM}$ each of reverse and forward primers, 2.5 U Taq DNA polymerase, and $10 \mu \mathrm{l}$ of bacterial lysate. Primers, size of DNA target sequences, and amplification conditions are shown in Table 1.

\section{Results}

A total of 59 distinct $E$. coli strains were isolated from $44(81.0 \%)$ of the 54 patients investigated. Seven strains belonged to the following EPEC classical O serogroups: O55, O126, O127 and O142 (one strain each) and O125 (three strains). None of them reacted with antisera for the most common $\mathrm{H}$ flagellar antigens $(\mathrm{H} 2, \mathrm{H} 4, \mathrm{H} 6, \mathrm{H} 7, \mathrm{H} 8, \mathrm{H} 9, \mathrm{H} 10$, $\mathrm{H} 12$, and $\mathrm{H} 21$ ).

Although all the strains were tested by PCR with primers used to detect the virulence genetic markers typical of DEC, only two were PCR positive: one had the eae gene and the other the EAEC plasmid. The eae+ strain belonged to serogroup $\mathrm{O} 125$ and the strain harboring the EAEC plasmid did not belong to any of the EPEC O serogroups.

When submitted to the assay of adherence to HEp-2 cells, the E. coli strains were grouped into three categories: adherent strains showing a characteristic adherence pattern after 3 or $6 \mathrm{~h}$ of incubation; strains displaying only a residual adherence (undefined adherence pattern) and strains that were not adherent. The strains with typical adherence were classified as either aggregative (AA) or diffuse (DA).

AA strains were isolated from 22 patients and DA from 12. Only one of the AA strains had the EAEC plasmid. With the exception of one AA strain, identified after a 3 -h incubation period, all of the remaining strains displaying AA, including the one harboring the EAEC plasmid, were detected 


\begin{tabular}{|c|c|c|c|c|c|c|c|}
\hline \multirow{2}{*}{$\begin{array}{l}\text { Virulence } \\
\text { marker }\end{array}$} & \multirow[t]{2}{*}{ Primers $\left(5^{\prime}-3^{\prime}\right)$} & \multirow{2}{*}{$\begin{array}{l}\text { Sequence } \\
\text { size (bp) }\end{array}$} & \multicolumn{3}{|c|}{ Amplification conditions } & \multirow[t]{2}{*}{ No. of cycles } & \multirow[t]{2}{*}{ References } \\
\hline & & & Denaturation & Annealing & Extension & & \\
\hline eae & $\begin{array}{l}\text { 1- ACGTTGCAGCATGGGTAACTC } \\
\text { 2- GATCGGCAACAGTTTCACCTG }\end{array}$ & 815 & $94^{\circ} \mathrm{C} / 1^{\prime}$ & $56^{\circ} \mathrm{C} / 2^{\prime}$ & $72^{\circ} \mathrm{C} / 1^{\prime}$ & 29 & 12 \\
\hline bfpA & $\begin{array}{l}\text { 1- AATCGTGCTTGCGCTTGCTGC } \\
\text { 2- GCCGCTTTATCCAACCTGGTA }\end{array}$ & 330 & $94^{\circ} \mathrm{C} / 30^{\prime \prime}$ & $56^{\circ} \mathrm{C} / 1^{\prime}$ & $72^{\circ} \mathrm{C} / 2^{\prime}$ & 28 & 13 \\
\hline sta & $\begin{array}{l}\text { 1- TTAATAGCACCCGGTACAAGCAGG } \\
\text { 2- CTTGACTCTTCAAAAGAGAAAATTAC }\end{array}$ & 147 & $94^{\circ} \mathrm{C} / 1^{\prime}$ & $55^{\circ} \mathrm{C} / 1^{\prime}$ & $72^{\circ} \mathrm{C} / 1^{\prime}$ & 29 & 14 \\
\hline ial & $\begin{array}{l}\text { 1- CTGGATGGTATGGTGAGG } \\
\text { 2- GGAGGCCAACAATTATTTCC }\end{array}$ & 320 & $94^{\circ} \mathrm{C} / 1^{\prime}$ & $43^{\circ} \mathrm{C} / 2^{\prime}$ & $72^{\circ} \mathrm{C} / 3^{\prime}$ & 25 & 15 \\
\hline $\begin{array}{l}\text { EAEC } \\
\text { plasmid }\end{array}$ & $\begin{array}{l}\text { 1- CTGGCCAAAGACTGTATCAT } \\
\text { 2- CAATGTATAGAAATCCGCTGTT }\end{array}$ & 630 & $94^{\circ} \mathrm{C} / 40^{\prime \prime}$ & $53^{\circ} \mathrm{C} / 1^{\prime}$ & $72^{\circ} \mathrm{C} / 1^{\prime}$ & 29 & 16 \\
\hline$s t \times 1^{*}$ & $\begin{array}{l}\text { 1- TTTACGATAGACTTCTCGAC } \\
\text { 2- CACATATAAATTATTTCGCTG }\end{array}$ & 227 & $94^{\circ} \mathrm{C} / 1^{\prime}$ & $48^{\circ} \mathrm{C} / 3^{\prime}$ & $72^{\circ} \mathrm{C} / 4^{\prime}$ & 34 & 17 \\
\hline$s t \times 2^{*}$ & $\begin{array}{l}\text { 1- TTTACGATAGACTTCTCGAC } \\
\text { 2- CACATATAAATTATTTCGCTG }\end{array}$ & 224 & $94^{\circ} \mathrm{C} / 1^{\prime}$ & $48^{\circ} \mathrm{C} / 3^{\prime}$ & $72^{\circ} \mathrm{C} / 4^{\prime}$ & 34 & 17 \\
\hline $\begin{array}{l}\text { EHEC } \\
\text { plasmid }\end{array}$ & $\begin{array}{l}\text { 1- ACGATGTGGTTTATTCTGGA } \\
\text { 2- CTTCACGTCACCATACATAT }\end{array}$ & 166 & $94^{\circ} \mathrm{C} / 1^{\prime}$ & $48^{\circ} \mathrm{C} / 3^{\prime}$ & $72^{\circ} \mathrm{C} / 4^{\prime}$ & 34 & 17 \\
\hline
\end{tabular}

Virulence markers: eae, E. coli attaching and effacing gene; bfpA, gene for the structural subunit of the EPEC bundle-forming pilus; sta, gene for the ETEC heat-stable enterotoxin; ial, EIEC invasion-associated locus; stx 1 and stx2, genes for the EHEC Shiga cytotoxins 1 and 2, respectively. *The search for stx1, stx2 and the EHEC plasmid was performed by multiplex PCR consisting of an initial denaturation at $94^{\circ} \mathrm{C} / 5^{\prime}$ preceding the 34 cycles of amplification indicated in the table.

Figure 1. EAEC and DAEC displaying the typical aggregative (A) and diffuse adherence (B) patterns, respectively, after $3 \mathrm{~h}$ of incubation with HEp-2 cell monolayers. May-Grünwald and Giemsa staining. Bar: $20 \mu \mathrm{m}$, in $A$ and $10 \mu \mathrm{m}$, in B.
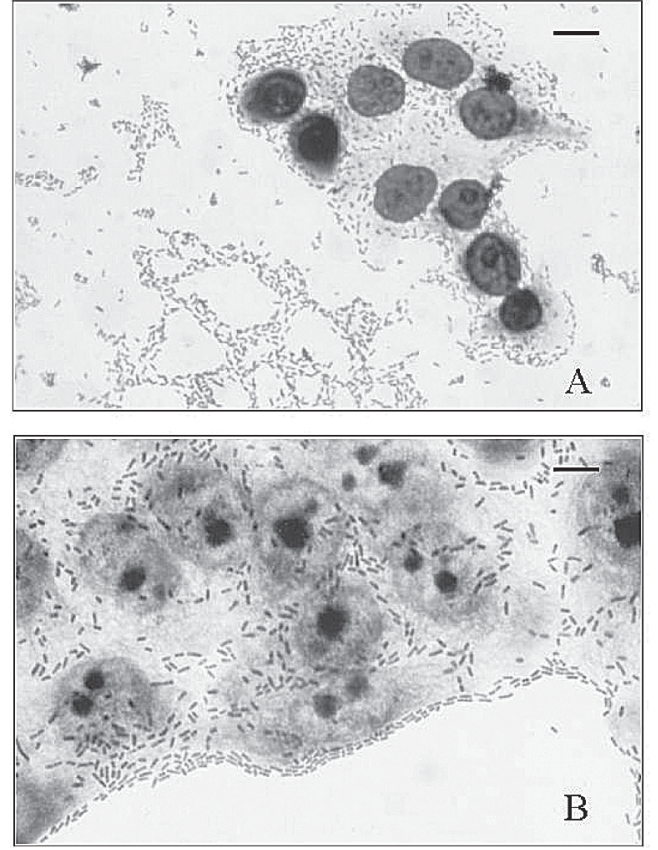

only after 6-h incubation. In contrast, all the 12 DA strains were detected during a 3-h incubation period. Multiple variants of the AA and DA pattern were observed, but they were not further subgrouped and are all referred to here as either enteroaggregative (EAEC) or diffusely (DAEC) adhering $E$. coli. Figure 1 shows a typical EAEC (panel A) and DAEC (panel B) strain.

No clear association was observed between serogroups and virulence genetic markers or adherence pattern of the strains. Though all the seven strains of the EPEC classical O serogroups adhered to the HEp-2 cells, no correlation was detected between serogroups and adherence pattern. With the exception of the O142 strain, which showed DA, all strains of the other serogroups displayed AA after 6-h incubation. 
Prevalence of enteropathogens, distribution of diarrhea cases, and isolation of rotavirus and EAEC

Of the 54 children investigated, 41 $(76.0 \%)$ had at least one of the following categories of enteropathogens: EAEC, rotavirus, DAEC, Salmonella, and Shigella. Among these, EAEC was dominant and was detected as a single agent in eleven $(20.4 \%)$ patients, followed by rotavirus, isolated from eight (14.8\%) patients (Figure 2).

Though the follow-up study was carried out from June 1997 to May 1998, the attendance of patients with diarrhea at the Health Center was recorded only from August 1997 to April 1998 (Figure 3). Most of the cases (22/54, 41.0\%) were from September 1997, a month when the bulk of rotavirus isolation $(16 / 22,73.0 \%)$ took place and the majority of EAEC strains were isolated.

\section{Discussion}

The incidence of infectious diarrhea and the prevalence of a given causal agent are strictly associated with socioeconomic factors such as nutrition, sanitation and habitat of the population. In developing countries, major diarrhea agents are protozoans, bacteria and rotavirus. The latter is a universal enteropathogen and accounts for most of the diarrhea cases in developed countries and in populations of high socioeconomic level of developing countries.

Several epidemiological studies on the prevalence of rotavirus have been carried out in Brazil since its initial detection in stools from diarrheic children in Pará State (18). According to hospital-based studies, the prevalence of rotavirus ranges from 13.0 to $40.0 \%$ of the cases of acute diarrhea and community-based studies have yielded an average of 0.25 rotavirus-related diarrheic episodes per child per year (19). In a survey conducted recently by Toporovski et al. (20), rotavirus was detected in $21.0 \%$ of children from high income families of São Paulo city. However, among low socioeconomic level children it has been observed that, while rotavirus accounts for $13.4 \%$ of the diarrhea cases, DEC are prevalent and isolated from $18.9 \%$ of the individuals (21). In the present study, $41.0 \%$ of the diarrheic children were found to have rotavirus as a single diarrhea agent or in association with bacterial enteropathogens. The rotavirus isolation peak occurred in late winter and early spring, a

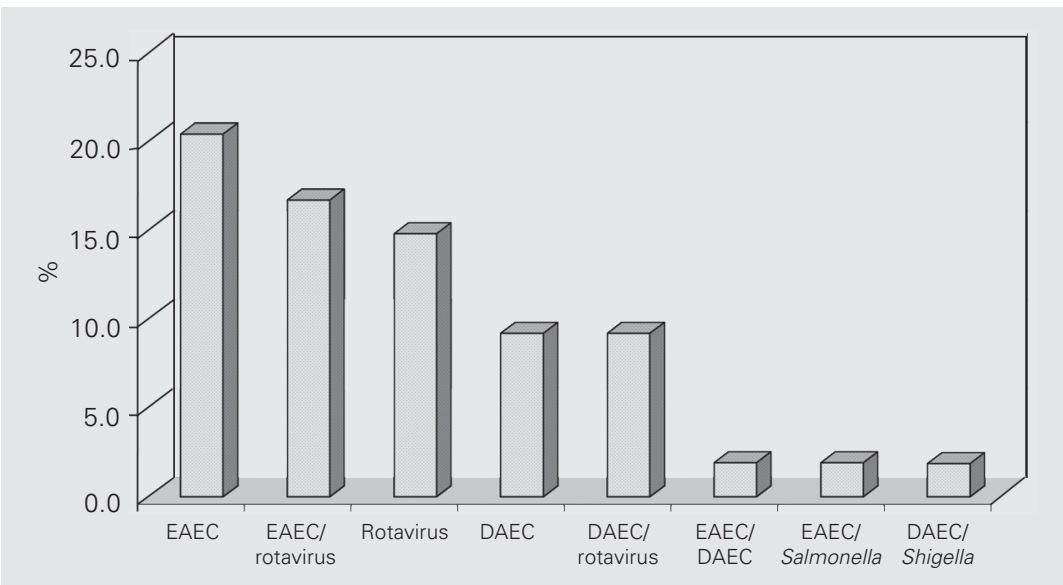

Figure 2. Prevalence of diarrheogenic Escherichia coli, rotavirus, Salmonella and Shigella among 54 diarrheic children. EAEC: enteroaggregative E. coli, DAEC: diffusely adhering $E$. coli.

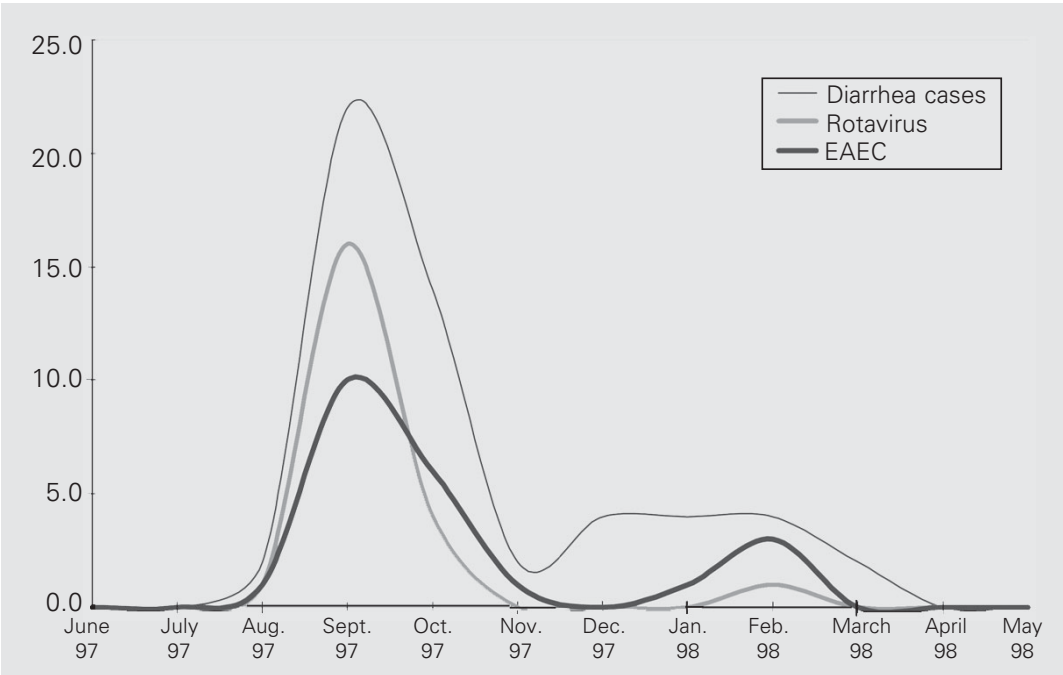

Figure 3. Seasonal distribution of the number of diarrhea cases and isolation of rotavirus and enteroaggregative Escherichia coli (EAEC). In the southern hemisphere the summer is June, July and August and winter is December, January and February. Since Botucatu is near the Tropic of Capricorn, the average temperature is near $22^{\circ} \mathrm{C}$ 
seasonal distribution similar to that observed recently by Zhou et al. in Japan (22), but distinct from the results of Gomes et al. (2), who found a higher rotavirus prevalence in the fall and winter in São Paulo. Overall, seasonality of rotavirus infections seems not to be evident in northern tropical areas of Brazil, but in central and southern states, a peak incidence during the driest months (May to September) has been noted (19). The reason for this local seasonal variation is unknown, but according to Parashar et al. (1), seasonality differences are commonly observed in tropical regions.

The characterization of E. coli and DEC identification were based on O:H serotyping, adherence assays and screening for virulence genetic markers. Since most of the strains were isolated from children up to one year old, an age group more susceptible to EPEC infection, we used only antisera to EPEC classical O antigens (23) in order to identify EPEC serogroups. By definition, EPEC have the eae, EAF (EPEC adherence factor) and the $b f p A$ genes and are able to express localized adherence to cultured epithelial cells (24). Strains with these characteristics usually belong to the serotypes O55:H6, O86:H34, O111:H2 and O119:H6 (23). In the present study, none of the strains investigated belonged to these serotypes or presented some of the EPEC virulence properties mentioned above. Similarly, strains of the other traditional DEC categories such as ETEC, EIEC or EHEC, as screened by their virulence genetic markers, were not detected among the isolates. Yet, a significant proportion of $E$. coli displaying the characteristic aggregative adherence pattern (EAEC) was found. EAEC was the most prevalent enteropathogen found as a single etiological agent in the population of children studied (Figure 2).

When considering associations between enteropathogens, EAEC and rotavirus were dominant. DAEC and rotavirus, the second most common enteropathogen association, followed them. Salmonella and Shigella were each isolated from only one patient.

In a previous study carried out in the same city in the 60's, Montelli (25) found that $70.0 \%$ of $E$. coli isolates from diarrheic children were typed as O111, a typical EPEC serogroup. Along with Shigella sp, these isolates were responsible for a significant proportion of the diarrhea cases. Since EPEC, as screened by a combination of three distinct assays (serotyping, adherence test, PCR for genetic markers), was not detected and EAEC was common among the patients of the present study, these results clearly reveal a temporal variation in the relative contribution of distinct DEC to the etiology of infantile diarrhea, expressed by a drop in the role of EPEC and emergence of EAEC as a putative new enteropathogenic category.

The identification of EAEC was based on its ability to express the characteristic stacked-brick aggregative adherence pattern (26). Nevertheless, the typical adherence does not reflect a homogeneous pathogenic category (27). Besides the expression of multiple variants of the aggregative adherence phenotype, which may reflect the presence of different surface adhesins, EAEC are also variable with regard to their ability to produce toxins (26). Among the toxigenic EAEC strains, at least two kinds of toxins have been described: EAST1 enterotoxin (28) and Pet cytotoxin (29). EAST1 is also found in EPEC and EHEC strains and may not be considered as a differential EAEC virulence marker (30). Two EAEC adhesins, AAF/I and $\mathrm{AAF} / \mathrm{II}$, have been described and fully characterized at the molecular level (31). However, most of the clinical isolates do not present the $\mathrm{AAF} / \mathrm{I}$ and $\mathrm{AAF} / \mathrm{II}$ gene sequences (aggA and aafA, respectively) (27). Similarly, according to some studies, only a low percentage of isolates have the AA sequence typical of the EAEC plasmid (26). Our data are in agreement with this finding, since we detected only one EAEC harboring the plasmid. 
The aforementioned observations underscore the difficulties in ascribing an etiological role in diarrhea to the multiple variants of EAEC isolated in the present study. There seems to be a consensus that not all strains displaying the AA adherence pattern have the same enteropathogenic potential and hence additional studies are necessary to identify new virulence factors in these bacteria, which could be used for their identification.

Our results 1) reveal that rotavirus contributes significantly to children diarrhea in Botucatu, 2) indicate that traditional DEC categories are not important enteropatho- gens in the local population, and 3) suggest that at least some of the EAEC strains may represent emerging and significant enteropathogens in the region, in view of their higher prevalence as a single agent in the population of children studied.

\section{Acknowledgments}

We are especially grateful to Dr. Terue Sadatsune for her contribution in establishing the collaboration link between the DMIIBB and Centro de Saúde Escolar group of investigators.

\section{References}

1. Parashar UD, Bresee JS, Gentsch JR \& Glass RI (1998). Rotavirus. Emerging Infectious Diseases, 4: 561-570.

2. Gomes TAT, Rassi V, MacDonald K, Ramos SR, Trabulsi LR, Vieira MAM, Guth BEC, Candeias JAN, Ivey C, Toled MRF \& Blake PA (1991). Enteropathogens associated with acute diarrheal disease in urban infants in São Paulo, Brazil. Journal of Infectious Diseases, 164: 331-337.

3. Bishop RF, Davidson GP, Holmes IH \& Ruck BJ (1973). Virus particles in epithelial cells of duodenal mucosa from children with acute non-bacterial gastroenteritis. Lancet, 2: 1281-1283.

4. Nataro JP \& Kaper JB (1998). Diarrheogenic Escherichia coli. Clinical Microbiology Reviews, 11: 142-201.

5. Wolf MK (1997). Occurrence, distribution, and associations of $\mathrm{O}$ and $\mathrm{H}$ serogroups, colonization factor antigens, and toxins of enterotoxigenic Escherichia coli. Clinical Microbiology Reviews, 10: 569-584.

6. Boerlin P, McEwen SA, Boerlin-Petzold F, Wilson JB, Johnson RP \& Gyles CL (1999). Associations between virulence factors of Shiga toxin-producing Escherichia coli and disease in humans. Journal of Clinical Microbiology, 37: 497-503.

7. Scaletsky ICA, Pelayo JS, Giraldi R, Rodrigues J, Pedroso MZ \& Trabulsi LR (1996). EPEC Adherence to HEp-2 cells. Revista de Microbiologia, 27 (Suppl I): 5872

8. Campos LC (1996). Conventional methods for the diagnosis of enteropathogenic Escherichia coli infections. Revista de Microbiologia, 27 (Suppl I): 50-53.
9. Chomczinski K \& Sachi N (1987). Single step method of RNA isolation by acid guanidinium thiocyanate-phenol chloroform extraction. Analytical Biochemistry, 162: 156-159.

10. Ewing WH (1986). The genus Escherichia. In: Ewing WH (Editor), Edwards and Ewing's Identification of Enterobacteriaceae. 4th edn. Elsevier Science Publishing Co., Inc., New York, NY, USA, 93-134.

11. Cravioto $A$, Gross RJ, Scotland $S M$ \& Rowe B (1979). An adhesive factor found in strains of Escherichia coli belonging to the traditional infantile enteropathogenic serotypes. Current Microbiology, 3: 9599.

12. Gannon VPJ, Rashed M, King RK \& Thomas EJ (1993). Detection and characterization of the eae gene of Shiga-like toxinproducing Escherichia coli using the polymerase chain reaction. Journal of Clinical Microbiology, 31: 1268-1274.

13. Gunzburg ST, Tornieporth NG \& Riley LW (1995). Identification of enteropathogenic Escherichia coli by PCR-based detection of the bundle-forming pilus gene. Journal of Clinical Microbiology, 33: 1375-1377.

14. Olsvik O \& Strockbine NA (1993). PCR detection of heat-stable, heat-labile, and Shiga-like toxin genes in Escherichia coli. In: Persing DH, Smith TF, Tenover FC \& White TJ (Editors), Diagnostic Molecular Microbiology. Principles and Applications. Mayo Foundation, New York, NY, USA

15. Frankel G, Riley L, Giron JA, Valmassoi J, Friedmann A, Strockbine N, Falkow S \& Schoolnik GK (1990). Detection of Shigella in feces using DNA amplification.
Journal of Infectious Diseases, 161: 12521256.

16. Schmidt $H$, Knop C, Franke $S$, Aleksic $S$, Heesemann J \& Karch H (1995). Development of PCR for screening of enteroaggregative Escherichia coli. Journal of Clinical Microbiology, 33: 701-705.

17. Fratamico PM, Sackitey SK, Wiedmann M \& Deng MY (1995). Detection of Escherichia coli 0157:H7 by multiplex PCR. Journal of Clinical Microbiology, 33: 21882191.

18. Linhares AC (1997). Rotavirus infection in Brazil: epidemiology, immunity, and potential vaccination. Brazilian Journal of Infectious Diseases, 1: 284-293.

19. Linhares AC (2000). Rotavirus infection in Brazil: epidemiology and challenges for its control. Cadeia de Saúde Pública, 16: 629-646.

20. Toporovski MS, Mimiça IM, Chieffi PP, Paschoalotti MA, Dias AMG \& Silva CB (1999). Diarréia aguda em crianças menores de 3 anos de idade: recuperação de enteropatógenos nas amostras fecais de pacientes comparada a de grupo controle. Jornal de Pediatria, 75: 97-104.

21. Gomes TAT, Griffin PM, Ivey C, Trabulsi LR \& Ramos STS (1996). EPEC infections in São Paulo. Revista de Microbiologia, 27 (Suppl I): 25-33.

22. Zhou I, Li L, Kim B, Kaneshi K, Nishimura S, Kuroiwa T, Nishimura T, Sugita K, Ueda Y, Nakaya S \& Ushijima H (2000). Rotavirus infection in children in Japan. Pediatrics International, 42: 428-439.

23. Trabulsi LR, Campos LC, Gomes TAT, Rodrigues J \& Goncalves AG (1996). Tra- 
ditional and non-traditional enteropathogenic Escherichia coli serogroups. Revista de Microbiologia, 27 (Suppl I): 1-6.

24. Kaper JB (1996). Defining EPEC. Revista de Microbiologia, 27 (Suppl I): 130-133.

25. Montelli AC (1972). Diarréias por enterobactérias. Estudo bacteriológico, clínico e epidemiológico. Doctoral thesis, Faculdade de Medicina, UNESP, Botucatu, SP, Brazil.

26. Nataro JP, Stainer T \& Guerrant RL (1998). Enteroaggregative Escherichia coli. Emerging Infectious Diseases, 4: 251261.

27. Elias WP, Suzart S, Trabulsi LR, Nataro JP
\& Gomes TA (1999). Distribution of aggA and aafA gene sequences among Escherichia coli isolates with genotypic or phenotypic characteristics, or both, of enteroaggregative E. coli. Journal of Medical Microbiology, 48: 597-599.

28. Savarino SJ, Fasano A, Robertson DC \& Levine MM (1991). Enteroaggregative Escherichia coli elaborate a heat-stable enterotoxin demonstrable in an in vitro rabbit intestinal model. Journal of Clinical Investigation, 87: 1450-1455.

29. Eslava C, Navarro-Garcia F, Czeczulin JR, Henderson IR, Cravioto A \& Nataro JP (1998). Pet, an autotransporter entero- toxin from enteroaggregative Escherichia coli. Infection and Immunity, 66: 31553163.

30. Savarino SJ, McVeigh A, Watson J, Cravioto A, Molina J, Echeverria P, Bhan MK, Levine MMF \& Fasano A (1996). Enteroaggregative Escherichia coli heatstable enterotoxin is not restricted to enteroaggregative E. coli. Journal of Infectious Diseases, 173: 1019-1022.

31. Nataro JP (1996). Non-EPEC Escherichia coli that adhere to HEp-2 cells. Revista de Microbiologia, 27 (Suppl I): 67-71. 